\title{
Social Media in English and Russian Language Consciousness. Article 1. Psycholinguistic experiments
}

\section{Социальные медиа в английском и русском языковом сознании. Статья 1. Психолингвистические эксперименты}

Svetlana Shlyakhova

Ph.D. in Philology, Head of the Chair of Foreign Languages and Public Relations

\section{Светлана Шляхова}

доктор филологических наук, завкафедрой иностранных языков

и связей с общественностью

E-mail: shlyahova@mail.ru https://orcid.org/0000-0002-5636-4837

Scopus AuthorID: 55934110900

ResearcherID: D-1271-2017

Nikita Klyuev

Senior lecturer
Никита Клюев

Старший преподаватель

E-mail: n.a.klyuev@gmail.com

https://orcid.org/0000-0003-4829-4469

ResearcherID: G-5111-2019

Perm National Research

Polytechnic University

$\triangle 29$, Komsomolsky Prospect,

Perm, Russia, 614990
Пермский национальный исследовательский политехнический университет $\checkmark$ Комсомольский проспект, 29, Пермь, Российская Федерация, 614990

Original manuscript received October 20, 2019

Revised manuscript accepted March 20, 2020 


\begin{abstract}
Introduction. This research is devoted to the systematic description of a concept "social media" in the Russian and English linguistic consciousness. The article consists of two parts. The first part is dedicated to the research of the concept in a serial psycholinguistic experiment. The second part includes the analysis of the concept's presence in text corpora and also the field and the classificational cognitive models of the concept. The first part describes nominative fields of the concept "social media" and its subconcepts and provides a cognitive interpretation and a comparative analysis of the data in Russian and English languages.
\end{abstract}

Methods of the research. The structure of the concept "social media" is set by the method of subjective definition of the word. The structure of subconcepts (social network, Facebook, Instagram, etc.) is set by the method of free associations. The procedure of cognitive interpretation sets cognitive classifiers of the concept. The significance of the quantitative analysis was diagnosed by the Fisher angular transformation method (criterion $\varphi$ ).

Results. The non-specific trait of the concept "social media" in Russian and English discourses is the identical classificational cognitive structure. Dissimilarities in the structure are noticeable only in the peripheral zones. The diffusion of the reactions (in various experiments) in the core and peripheral zones shows that the concept "social media» is socially and culturally specific.

Conclusion. The results can be useful in the development of psycholinguistics 2.0, sociolinguistics, computational linguistics $(O C R, A S R$, data mining, automatic translation, etc.), lexicography, etc.

Key words: social media, social networks, psycholinguistics 2.0, language consciousness, psycholinguistic experiment, English, Russian.

\title{
Введение
}

Социальные медиа представляют собой объект (комплекс объектов, явлений, акторов, связей), с которым взаимодействует значительная часть современного общества. Они оказывают влияние на социальные, политические, экономические процессы, что, в свою очередь, отражается на обществе в целом и на людях, которые не являются их пользователями (гражданские и политические активности, которые используют координационный и аккумулирующий потенциал социальных медиа, оказывая влияние на гораздо большее количество социальных групп, нежели просто на пользователей социальных медиа). Это говорит о глубинном проникновении социальных медиа в жизнь современного общества. 
Social Media in English and Russian Language Consciousness...

Феномен социальных медиа привлекает пристальное внимание ученых. Существуют научные журналы (Social Media and Society, Journal of Digital and Social Media Marketing, Online Social Networks and Media и др.) и исследовательские лаборатории (Social and Evolutionary Neuroscience Research Group Оксфордского университета; The Human Nature Lab Йельского института сетевых наук; Лаборатория интернет-исследований и Международная лаборатория прикладного сетевого анализа (ANR-Lab) Высшей школы экономики; Лаборатория Интернета Вещуей СанктПетербургского государственного университета телекоммуникаций и др., которые занимаются проблемами социальных медиа.

Наукометрические данные (на 20.02.2020) показывают, что в англоязычном дискурсе наблюдается некоторый спад интереса к данной проблематике, в то время как в русскоязычном дискурсе количество публикаций возрастает (рис. 1-2).

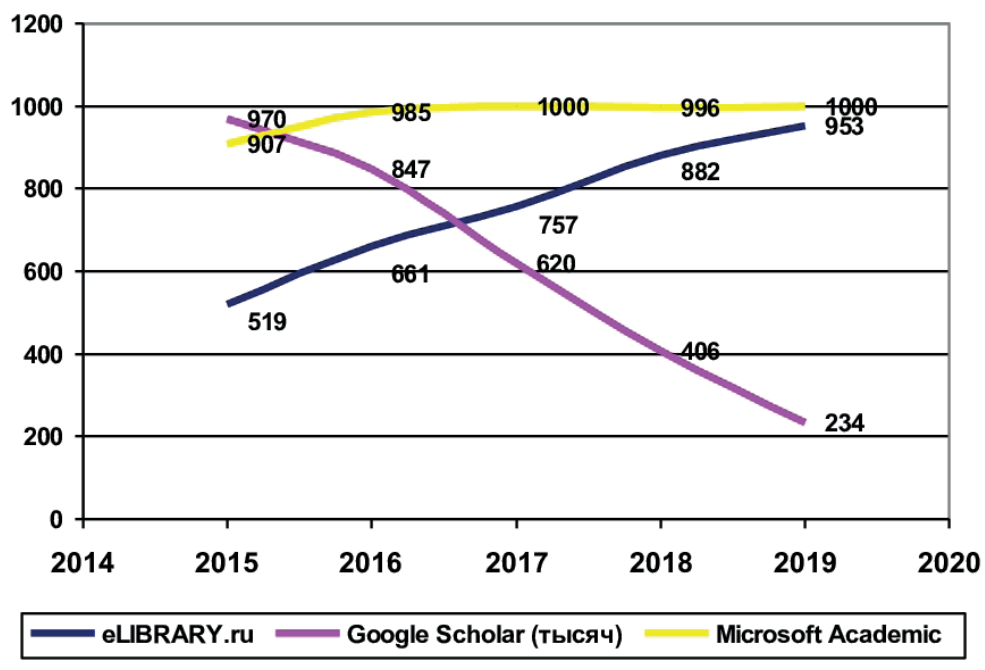

Рис. 1. Количество публикаций по запросу сощииальные медиа/social media

На основе метаданных социальных сетей исследуются естественное и неестественное онлайн-поведение (Guo et al., 2009; Winata \& Andangsari, 2017; Stine \& Agarwal, 2019), поляризация интернет-пользователей и проблема дезинформации в социальных сетях (Schmidt et al., 2017), идентификация автоматизированной деятельности в социальных сетях, в том числе обнаружение 
социальных ботов (Gilani et al., 2016; Grimme et al., 2018; Stine et al., 2018) и влияние их использования на мнения и поведение людей (Bail, 2018), поведенческие характеристики ботов и людей (Gilani et al., 2017), проблема распознавания пары человек-бот (Chu et al., 2012) для надежной классификации ботов и изучения автоматизированной политической инфильтрации и рекламных кампаний (Gilani et al., 2017), а также для выявления вредоносных стратегических атак на общественное мнение (Grimme et al., 2018).

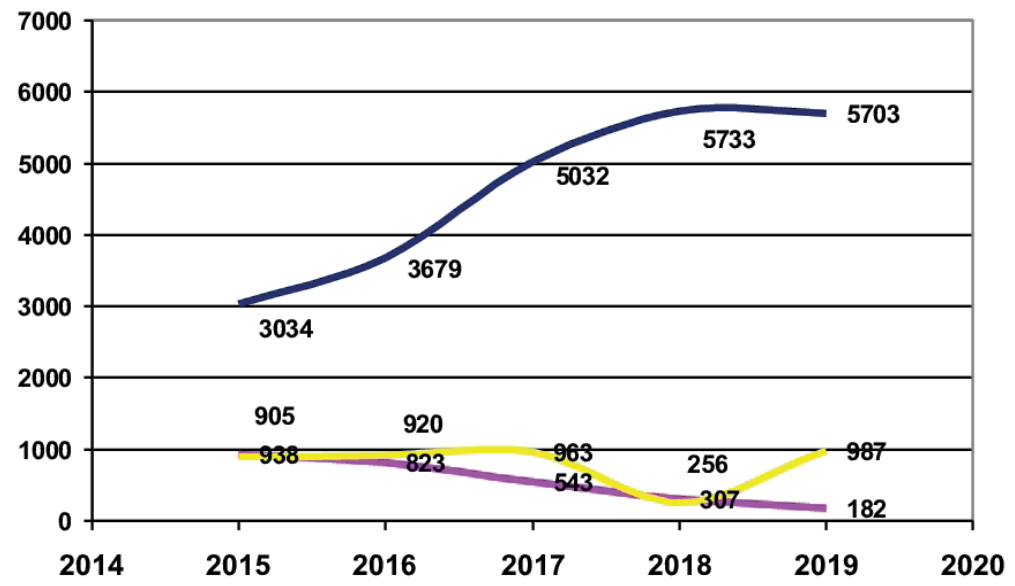

eLIBRARY.ru $=$ Google Scholar (тысяч) Microsoft Academic

Рис. 2. Количество публикаций по запросу социильные cemu/social networks

Big Data предлагают широкие возможности для решения вопросов о социальном поведении людей на платформах социальных сетей через анализ мнений, выраженных через сообщения. Однако исследования не должны отказываться от традиционно критериев, таких как репрезентативность данных и качество выборки (Hargittai, 2018). Нерепрезентативность имеет серьезные последствия для исследований, использующих социальные медиа в качестве источника данных. Данные социальных сетей не могут быть использованы для обобщения на любую другую совокупность, кроме самих социальных сетей. Результаты свидетельствуют о том, что ни одна социальная медиа-платформа не является репрезентативной для всей генеральной совокупности (всего населения). Использования контента с таких сайтов в качестве 
единственной базы данных нерелевантно, будь то деловые или политические интересы. Важно, чтобы решения, которые касаются всего населения, не основывались на результатах анализа соцсетей (Blank \& Lutz, 2017; Hargittai, 2018).

В данном случае использование результатов по отражению концепта coųuальные медиа / social media в русском и английском языковом сознании при помощи сетевого анализа позволит скорректировать выводы, полученные с помощью Big Data.

Развитие технологических коммуникационных платформ отражается не только на социальном, но и на психологическом, ментальном уровне. В этой связи изучение когнитивных аспектов феномена социальных медиа представляется чрезвычайно перспективным.

Статья посвящена изучению концептов социальные медиа/ social media в русскоязычном и англоязычном языковом сознании. В одном из последних русских словарей «Концептосфера русского языка. Ключевые концепты и их репрезентации в языке и речи» (Бабенко, 2018), включающем около 200 концептов, концепт социиальные медиа не получает описания.

В рамках психолингвистики концепт couуиальные медиа/ social media исследуется не так активно. Однако в Украине в последнее время активизировался интерес психолингвистики к данной проблематике (Камінська, Стежно \& Глєбова, 2019; Шебанова \& Яблонська, 2019; Акімова \& Олександренко, 2019; Храбан, 2019 и др.). Исследователи говорят о новом направлении психолингвистики:

«психолингвистики 2.0, изучающей психологические и лингвистические аспекть речевой деятельности человека в соииальных медиа» (Горошко \& Полякова, 2019: 28).

Нам не известны специальные работы, посвященные системному описанию феномена социильные медиa/social media как концепта. Однако отдельные исследования определяют ассоциативную структуру наиболее популярных сервисов социального веба (Интернет, Инстаграм, социиальные медиа, коммуникация, Твиттер, Телеграм, ВатсАn, Ютуб, Пинтрест, Гугл, селфи, Фейсбук) (Горошко \& Полякова, 2019).

Цель исследования - представить системное описание концепта coųuальные медиa/social media, выявив когнитивные компоненты 
отражения концепта в сознании пользователей, а также социо- и культурспецифичные аспекты концепта в русском и английском языковом сознании.

\section{Методы и методики исследования}

Основные методы исследования - психолингвистический эксперимент (метод субъективной дефиниции и свободный ассоциативный эксперимент) и когнитивная интерпретация.

Метод субъективной дефиниции (эксперименты 1-2): всего опрошено 707 человек (497 русскоязычных, 210 англоязычных); получено 672 дефиниции при 35 отказах. Метод свободного ассоциативного эксперимента (эксперименты 3-4): всего опрошено 842 респондента (632 русскоязычных, 210 англоязычных); получено 6814 реакций при 250 отказах.

Основную долю респондентов составили респонденты в возрасте от 18 до 27 лет (62,0\%); 59,0\% - мужчины, 41,0\% женщины. В число англоязычных респондентов вошли жители Великобритании, США, Индии, Канады, Австралии и ряда других стран; русскоязычных - жители России.

При большой численности экспериментальной группы целесообразным было использование метода случайного отбора с применением процедуры рандомизации, что позволило снизить вероятность отбора испытуемых одного типа.

Процедура когнитивной интерпретации включает несколько этапов. На первом этапе выявляются когнитивные признаки концепта, которые ранжируются по яркости. Индекс яркости (термин И.А. Стернина) вычисляется как отношение количества реакций к общему числу опрошенных. Когнитивный признак - минимальный структурный компонент концепта, отражающий отдельный признак концепта. На втором этапе ранжирование позволяет распределить когнитивные признаки по зонам - ядро, ближняя, дальняя и крайняя периферия. На третьем этапе когнитивные признаки объединяются в более крупные - классификационные - когнитивные признаки (когнитивные классификаторы), которые используются для концептуализации явления и определения актуальности отдельных когнитивных классификаторов в структуре концепта (Попова \& 
Стернин, 2007). Название классификатору присваивалось либо по названию самого частотного признака, либо по номинации с самой широкой семантикой, либо отвлечённым понятием, если его не было в числе интегральных признаков.

Значимость количественного анализа диагностировалось при помощи метода углового преобразования Фишера (критерий $)$ ).

\section{Результаты}

\section{1. Эксперименты 1-2: метод субъективной дефиниции}

Выборка: в эксперименте приняло участие 497 русскоязычных респондентов, получено 475 дефиниций при 22 отказах (эксперимент 1); 210 - англоязычных, получено 197 дефиниций при 13 отказах (эксперимент 2).

Форма: сетевой опрос.

Инструкция: «Пожалуйста, дайте своё определение понятию социальные медиа/social media (как вы его понимаете). Социальные медиа/social media - это ...».

1.1. Концепт социальные медиа (эксперимент 1). Перечень когнитивных признаков, полевая структура и классификационные когнитивные признаки концепта социальные медиа, полученных в ходе эксперимента, представлены в таблицах 1-3.

Таблица 1. Когнитивные признаки концепта социальные медиа

\begin{tabular}{|c|c|c|c|c|c|}
\hline $\begin{array}{c}\text { Когнитивный } \\
\text { признак }\end{array}$ & $\begin{array}{c}\text { Количество } \\
\text { реакций }\end{array}$ & $\begin{array}{c}\text { Индекс } \\
\text { яркости (\%) }\end{array}$ & $\begin{array}{c}\text { Когнитивный } \\
\text { признак }\end{array}$ & $\begin{array}{c}\text { Количество } \\
\text { реакций }\end{array}$ & $\begin{array}{c}\text { Индекс } \\
\text { яркости (\%) }\end{array}$ \\
\hline социиальный & 123 & 9,8 & аудио & 19 & 1,5 \\
\hline коммуникация & 120 & 9,6 & взаимодействие & 15 & 1,2 \\
\hline информация & 120 & 9,6 & изображения & 15 & 1,2 \\
\hline люди & 87 & 6,9 & канал & 14 & 1,1 \\
\hline $\begin{array}{l}\text { сочиальные } \\
\text { сети }\end{array}$ & 77 & 6,1 & развлечение & 14 & 1,1 \\
\hline интернет & 66 & 5,3 & платформа & 13 & 1,0 \\
\hline $\begin{array}{l}\text { массовая } \\
\text { аудитория }\end{array}$ & 52 & 4,1 & площчадки & 13 & 1,0 \\
\hline $\begin{array}{l}\text { средства } \\
\text { массовой } \\
\text { информацчии }\end{array}$ & 50 & 4,0 & работа & 11 & 0,9 \\
\hline
\end{tabular}


Социальные медиа в английском и русском языковом сознании...

\begin{tabular}{|c|c|c|c|c|c|}
\hline медиа & 46 & 3,7 & реклама & 11 & 0,9 \\
\hline новости & 44 & 3,5 & приложения & 10 & 0,8 \\
\hline контент & 42 & 3,3 & caŭmbl & 9 & 0,7 \\
\hline $\begin{array}{l}\text { негативная } \\
\text { оценка }\end{array}$ & 40 & 3,2 & интерес & 9 & 0,7 \\
\hline $\begin{array}{l}\text { распространение } \\
\text { информации }\end{array}$ & 39 & 3,1 & инструмент & 8 & 0,6 \\
\hline связь & 35 & 2,8 & технологии & 8 & 0,6 \\
\hline способ & 29 & 2,3 & сообщества & 7 & 0,6 \\
\hline ресурс & 26 & 2,1 & блоги & 7 & 0,6 \\
\hline видео & 24 & 1,9 & $\begin{array}{l}\text { позитивная } \\
\text { оценкка }\end{array}$ & 5 & 0,4 \\
\hline пользователи & 22 & 1,8 & потребители & 4 & 0,3 \\
\hline помощьь & 22 & 1,8 & & & \\
\hline
\end{tabular}

Значительную долю признаков составляют номинации, входящие в словосочетание-репрезентант концепта: соичиальный (123) и медиа (46). Это означает, что слово-репрезентант обладает низкой степенью идиоматизации и, соответственно, низкой коммуникативной релевантностью.

Таблица 2. Полевая организация концепта соичиальные медиа

\begin{tabular}{|c|c|c|}
\hline Уровень & Когнитивные признаки & $\begin{array}{c}\text { Индекс } \\
\text { яркости (\%) }\end{array}$ \\
\hline Ядро & Социальный, коммуникация, информация & 29,0 \\
\hline $\begin{array}{l}\text { Ближняя } \\
\text { периферия }\end{array}$ & $\begin{array}{l}\text { Люди, соииальные сети, интернет, массовая аудитория, } \\
\text { средства массовой информации, медиа, новости, контент, } \\
\text { негативная оценка, распространение информации }\end{array}$ & 43,2 \\
\hline $\begin{array}{l}\text { Дальняя } \\
\text { периферия }\end{array}$ & $\begin{array}{l}\text { Связь, способ, ресурс, видео, пользователи, помощьь, } \\
\text { аудио, взаимодействие, изображения, канал, развлечение, } \\
\text { платформа, площадки, работа, реклама, приложения }\end{array}$ & 20,0 \\
\hline $\begin{array}{l}\text { Крайняя } \\
\text { периферия }\end{array}$ & Работа, реклама, приложения, < ..>. & 7,8 \\
\hline
\end{tabular}

Ядерная часть номинативного поля концепта сощчиальные медиа образована признаками люди, информацчия, коммуникацчия.

Данные, полученные в Украине, несколько отличаются, что позволяет говорить о социо- и культурспецифичности концепта. Термин социиальные медиа не очень знаком украинским 
информантам: на первом месте по частоте $(20,36 \%)$ стоит отказ от реагирования (для сравнения в России отказы - 4,6\%). Чаще всего социальные медиа представляют как общение, тусовку, информацию, телевидение, рекламу, новости и пропаганду, а также ассоциируют с социальнылми сетяли, в т. ч. с конкретными сервисами Фейсбук, Инстаграм, Телеграмм, Ютуб. Информационная функция выходит на первый план: социальные медиа выступают как СМИ или как их альтернатива (Горошко \& Полякова, 2019).

Таблица 3. Классификационные когнитивные признаки концепта сощчиальныле медиа

\begin{tabular}{|c|c|c|}
\hline $\begin{array}{c}\text { Классификационные } \\
\text { когнитивные признаки }\end{array}$ & $\begin{array}{l}\text { Вербальная репрезентация, } \\
\text { количество реакций }\end{array}$ & $\begin{array}{c}\text { Индекс } \\
\text { яркости (\%) }\end{array}$ \\
\hline Люди & 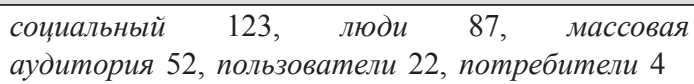 & 22,9 \\
\hline Информация & $\begin{array}{l}\text { информация 120, новости 44, контент 42, } \\
\text { видео } 24 \text {, аудио } 19 \text {, изображения } 15 \text {, реклама } 11\end{array}$ & 21,9 \\
\hline Коммуникация & коммуникация 120, связь 35, взаимодействие 15 & 16,6 \\
\hline Pecypc & $\begin{array}{l}\text { способ 29, ресурс 26, канал 14, площяадки } 13, \\
\text { платформа 13, приложения 10, сайть } 9 \text {, } \\
\text { инструмент } 8\end{array}$ & 9,7 \\
\hline Медиа & СМИ 50, медиа 46 & 7,6 \\
\hline Социальные сети & & 6,1 \\
\hline Интернет & интернет 66, технологии 8 & 5,9 \\
\hline Общая оценка & негативная оценка 40, позитивная оценка 5 & 3,6 \\
\hline Помощь & & 1,8 \\
\hline Развлечение & & 1,1 \\
\hline Работа & & 0,9 \\
\hline Интерес & & 0,7 \\
\hline Блоги & & 0,6 \\
\hline Сообщества & & 0,6 \\
\hline
\end{tabular}

1.2. Концепт social media (эксперимент 2). Перечень когнитивных признаков, полевая структура и классификационные когнитивные признаки концепта social media, полученных в ходе эксперимента, представлены в таблицах (табл. 4-6).

В целом social media определяется как «online platform for connecting with friends and for sharing some information». Ключевым признаком концепта выступает признак connect (связь). В перечень 
признаков входят website, network, app, site, что указывает на то, что концепт social media включает определённое количество элементов.

Таблица 4. Когнитивные признаки концепта social media

\begin{tabular}{lcclcc}
\hline $\begin{array}{l}\text { Когнитивный } \\
\text { признак }\end{array}$ & $\begin{array}{c}\text { Количество } \\
\text { реакций }\end{array}$ & $\begin{array}{c}\text { Индекс } \\
\text { яркости (\%) }\end{array}$ & $\begin{array}{c}\text { Когнитивный } \\
\text { признак }\end{array}$ & $\begin{array}{c}\text { Количество } \\
\text { реакций }\end{array}$ & $\begin{array}{c}\text { Индекс } \\
\text { яркости (\%) }\end{array}$ \\
\hline connect & 22 & $\mathbf{1 2 , 0}$ & media & 4 & 2,2 \\
friend & 17 & $\mathbf{9 , 3}$ & sharing & 4 & 2,2 \\
platform & 15 & $\mathbf{8 , 2}$ & world & 4 & 2,2 \\
share & 13 & $\mathbf{7 , 1}$ & app & 3 & 1,6 \\
online & 12 & $\mathbf{6 , 6}$ & communicate & 3 & 1,6 \\
life & 8 & 4,4 & contact & 3 & 1,6 \\
family & 6 & 3,3 & idea & 3 & 1,6 \\
place & 6 & 3,3 & image & 3 & 1,6 \\
social & 6 & 3,3 & interaction & 3 & 1,6 \\
website & 6 & 3,3 & interest & 3 & 1,6 \\
interact & 5 & 2,7 & news & 3 & 1,6 \\
internet & 5 & 2,7 & opinion & 3 & 1,6 \\
network & 5 & 2,7 & positive & 3 & 1,6 \\
use & 5 & 2,7 & site & 3 & 1,6 \\
communication & 4 & 2,2 & talk & 3 & 1,6 \\
\hline
\end{tabular}

Таблица 5. Полевая организация концепта social media

\begin{tabular}{llc}
\hline \multicolumn{1}{c}{ Уровень } & \multicolumn{1}{c}{ Когнитивные признаки } & $\begin{array}{c}\text { Индекс } \\
\text { яркости (\%) }\end{array}$ \\
\hline Ядро & Connect & 12,0 \\
Ближняя периферия & Friend, platform, share, online & 31,2 \\
Дальняя периферия & $\begin{array}{l}\text { Life, family, place, social, website, interact, } \\
\text { internet, network, use }\end{array}$ & 31,7 \\
Крайняя периферия & Communication, media, sharing $<\ldots .$. & 25,1 \\
\hline
\end{tabular}

Таблица 6. Классификационные когнитивные признаки концепта social media

\begin{tabular}{llc}
\hline $\begin{array}{c}\text { Когнитивные } \\
\text { признаки }\end{array}$ & \multicolumn{1}{c}{ Вербальная репрезентация } & $\begin{array}{c}\text { Индекс } \\
\text { яркости (\%) }\end{array}$ \\
\hline $\begin{array}{l}\text { Connection and } \\
\text { communication }\end{array}$ & $\begin{array}{l}\text { connect, social, interact, network, communication, sharing, } \\
\text { communicate, contact, interaction, talk, connection, groups, } \\
\text { communicating, community, connected, coworker, public, } \\
\text { shared, together }\end{array}$ & 13,7 \\
\hline
\end{tabular}


Social Media in English and Russian Language Consciousness...

\begin{tabular}{|c|c|c|}
\hline Platform & $\begin{array}{l}\text { platform, place, website, network, media, app, site, } \\
\text { medium, base, service, hub, infrastructure, system, tool }\end{array}$ & 10,0 \\
\hline People & $\begin{array}{l}\text { friend, family, social, anyone, celebrity, groups, publicly, } \\
\text { community, coworker, everyone, person, personal, public, } \\
\text { someone, user, follower, mass }\end{array}$ & 9,6 \\
\hline Internet & $\begin{array}{l}\text { online, website, internet, site, digital, electronic, virtual, } \\
\text { virtually }\end{array}$ & 6,0 \\
\hline Evaluation & $\begin{array}{l}\text { positive, good, love, beauty, care, discover, easy, engaging, } \\
\text { useful, negative, waste, addictive, boring, controlled, fuck, } \\
\text { isolating, nonsense, passive, thief }\end{array}$ & 5,0 \\
\hline Content & $\begin{array}{l}\text { idea, image, opinion, information, message, photo, chat, } \\
\text { meme, messaging, pic, post, word }\end{array}$ & 4,2 \\
\hline
\end{tabular}

Ядерную часть его структуры концепта social media составляют признаки connection and communication, platform, people. Доля оценочных признаков невысока (5,0\%): 2,6\% - положительная оценка (positive, good, love и т. д.), 2,4\% - негативная оценка (waste, boring, isolating и т. д.).

1.3. Концепт социальные медиа/sоcial media: сравнительный анализ (эксперименты 1-2). Представим к сравнению полевую структуру и когнитивные классификаторы концептов социальные медиа и social media (табл. 7-8).

Таблица 7. Полевая организация концептов социальные медиа/social media

\begin{tabular}{lll}
\hline \multicolumn{1}{c}{ Уровень } & \multicolumn{1}{c}{ Социальные медиа } & \multicolumn{1}{c}{ Social media } \\
\hline Ядро & Социальный, коммуникация, информация & Connect \\
Ближняя & Люди, социальные сети, интернет, массовая аудитория, & Friend, \\
периферия & средства массовой информации, медиа, новости, platform, share, \\
& контент, негативная оценка, распространение & online \\
& информации & \\
\hline
\end{tabular}

Полученные данные позволяют отметить некоторые содержательные пересечения в репрезентации концепта в русском и английском языковом сознании. Пары признаков коммуникаиия/ connect; интернет/online, platform выявляют близкие когнитивные признаки. При этом пары признаков информация/share; люди/ friends также отражают когнитивные единицы одного порядка: пользователи делятся (share) информацией в социальных медиа; близкий круг каждого пользователя - его друзья (friends) и 
семья (family). Однако при сходстве пар признаков людu/friends и коммуникация/connect русскоязычные респонденты отражают более формализованное, обезличенное представление о взаимодействии пользователей социальных медиа, в то время как англоязычные репрезентируют более личностное, неформальное представление.

Рассмотрим категориальную структуру концептов социальные медиa/social media в сравнении (табл. 8).

Таблица 8. Классификационная когнитивная структура концептов социальные медua/social media

\begin{tabular}{lclc}
\hline $\begin{array}{c}\text { Когнитивный признак } \\
\text { (русский язык) }\end{array}$ & $\begin{array}{c}\text { Индекс } \\
\text { яркости (\%) }\end{array}$ & $\begin{array}{c}\text { Когнитивный признак } \\
\text { (английский язык) }\end{array}$ & $\begin{array}{c}\text { Индекс } \\
\text { яркости (\%) }\end{array}$ \\
\hline Люди & 22,9 & connection and coтmипication & 13,7 \\
Информация & 21,9 & platform & 10,0 \\
Коммуникация & 16,6 & people & 9,6 \\
Ресурс & 9,7 & internet & 6,0 \\
Медиа & 7,6 & evaluation & 5,0 \\
Социальные сети & 6,1 & content & 4,2 \\
Интернет & 5,9 & & \\
Общая оценка & 3,6 & & \\
Помощьь & 1,8 & & \\
Развлечение & 1,1 & & \\
Работа & 0,9 & & \\
Интерес & 0,7 & & \\
Блоги & 0,6 & & \\
Сообщества & 0,6 & & \\
\hline
\end{tabular}

На уровне классификационных признаков сходство структур концепта в сознаниях разноязычных пользователей становится очевиднее. Выделяются пары признаков, которые отражают одинаковые аспекты концепта вне зависимости от языка: люди/ people, коммуникация/connection and communication, pecypc/platform, информащия/content, общая оценка/evaluation, интернет/internet. Указанные пары признаков имею разную яркость в структурах концептов соииальные медиа/social media.

Рассчитаем достоверность различий между значениями в двух выборках при помощи углового преобразования Фишера (критерий ф) (табл. 9). 
Таблица 9. Угловое преобразование Фишера для парных признаков концептов социальнье медиа/social media

\begin{tabular}{lll}
\hline \multicolumn{1}{c}{ Парные когнитивные признаки } & $\boldsymbol{\varphi}_{\text {элип }}^{*}$ & \multicolumn{1}{c}{ Значимость } \\
\hline люди / pеорle & $\mathbf{4 , 4 9 5}$ & значимо \\
коммуникация / connection and communication & 0,941 & незначимо \\
ресурс / platform & 0,146 & незначимо \\
информация / content & $\mathbf{6 , 7 0 4}$ & значимо \\
общзая оценка / evaluation & 1,018 & незначимо \\
Интернет / Internet & 0,147 & незначимо \\
\hline
\end{tabular}

Значимыми различиями обладают признаки люди/people и uнформация/content. Русскоязычные признаки тяготеют к ядру классификационной структуры концепта сильнее, чем аналогичные признаки в английском языке. Для остальных парных признаков разница в яркости оказывается незначимой. Вероятно, подобная ситуация является следствием глобализации, в том числе общего пользовательского и коммуникативного опыта испытуемых вне зависимости от языка.

\section{2. Эксперименты 3-4: свободный ассоциативный эксперимент}

Выборка: в эксперименте приняло участие 632 русскоязычных респондентов, получено 5516 реакций при 165 отказах (эксперимент 3); 210 - англоязычных, получено 1298 реакций при 85 отказах (эксперимент 4).

Количество полученных реакций на отдельные стимулы (субконцепты) концепта couуиальные медиa/social media представлено в таблице 10 .

Таблица 10. Стимулы: свободный ассоциативный эксперимент

\begin{tabular}{|c|c|c|c|c|c|}
\hline $\begin{array}{c}\text { Стимул } \\
\text { (субконцепт) } \\
\text { русский } \\
\text { (эксперимент 3) }\end{array}$ & $\begin{array}{c}\text { Количество } \\
\text { реакций }\end{array}$ & $\begin{array}{c}\text { Количество } \\
\text { отказов }\end{array}$ & $\begin{array}{c}\text { Стимул } \\
\text { (субконцепт) } \\
\text { английский } \\
\text { (эксперимент 4) }\end{array}$ & $\begin{array}{c}\text { Количество } \\
\text { реакций }\end{array}$ & $\begin{array}{c}\text { Количество } \\
\text { отказов }\end{array}$ \\
\hline $\begin{array}{l}\text { Социальная } \\
\text { сеть }\end{array}$ & 660 & 2 & social network & 226 & 6 \\
\hline $\begin{array}{l}\text { Facebook / } \\
\text { Фейсбук }\end{array}$ & 971 & 9 & Facebook & 231 & 6 \\
\hline $\begin{array}{l}\text { Instagram / } \\
\text { Инстаграм }\end{array}$ & 964 & 26 & Instagram & 238 & 5 \\
\hline
\end{tabular}


Социальные медиа в английском и русском языковом сознании..

\begin{tabular}{lcclcc}
\hline Мессенджер & 824 & 29 & messenger & 227 & 5 \\
Viber / Вайбер & 581 & 32 & Viber & 158 & 52 \\
$\begin{array}{l}\text { WhatsApp / } \\
\text { Baтсап }\end{array}$ & 550 & 63 & WhatsApp & 218 & 11 \\
$\begin{array}{l}\text { ВКонтакте } \\
\text { Итого }\end{array}$ & 966 & 4 & & & \\
\hline
\end{tabular}

Англоязычный эксперимент со стимулом ВКонтакте не проводился в силу географической специфики социальной сети: она популярна в странах с высокой долей русскоязычного населения (Россия, Украина, Белоруссия, Казахстан).

Форма: сетевой опрос.

Инструкция: Напишите первое, что приходит в голову, когда вы слылшите .... (определённый стимул).

Исследуемые стимулы (табл. 7).

Анализ полученных в ходе экспериментов 3-4 реакций проводился по методике, описанной выше. В результате были получены расширенные данные по структуре концептов социальные медиa/social media за счет входящих в них субконцептов.

В силу экономии места и однотипности представляемого материала опустим количественные данные по отдельным субконцептам, которые представлены в других публикациях (Клюев, 2016a, 2016b, 2018a, 2018b). Рассмотри для примера только субконцепт Instagram/Инстаграм.

2.1. Субконцепт Instagram/Инстаграм. Когнитивные признаки (в сравнении с данными в Украине), полевая организация и когнитивные классификаторы субконцепта Instagram/Инстаграм представлены в таблицах 11-13.

Таблица 11. Когнитивные признаки субконцепта Instagram/Инстаграм

\begin{tabular}{|c|c|c|c|c|}
\hline \multirow{2}{*}{$\begin{array}{c}\text { Когнитивный } \\
\text { признак }\end{array}$} & \multicolumn{2}{|c|}{$\begin{array}{c}\text { Наши данные, } \\
\text { 2017-2018 (Россия) }\end{array}$} & \multicolumn{2}{|c|}{$\begin{array}{c}\text { Данные Е. Горошко и } \\
\text { T. Поляковой, } 2019 \text { (Украина) }\end{array}$} \\
\hline & $\begin{array}{c}\text { Количество } \\
\text { реакций }\end{array}$ & $\begin{array}{c}\text { Индекс } \\
\text { яркости (\%) }\end{array}$ & $\begin{array}{c}\text { Количество } \\
\text { реакций }\end{array}$ & $\begin{array}{c}\text { Индекс } \\
\text { яркости (\%) }\end{array}$ \\
\hline Отказы & 26 & 2,7 & 63 & 19,14 \\
\hline Фото & 303 & 38,7 & 84 & 25,5 \\
\hline Картинки & 30 & 3,8 & 25 & 7,6 \\
\hline Сочиальная сеть & 25 & 3,2 & 4 & 1,2 \\
\hline
\end{tabular}


Social Media in English and Russian Language Consciousness...

\begin{tabular}{|c|c|c|c|c|}
\hline Eда & 24 & 3,1 & 0 & 0 \\
\hline $\begin{array}{l}\text { ТП (аббревиатура в } \\
\text { соисетях тупая } п . . .)\end{array}$ & 12 & 1,5 & 0 & 0 \\
\hline селфи & 11 & 1,4 & 2 & 0,6 \\
\hline Квадрат & 9 & 1,1 & 0 & 0 \\
\hline Губы уточкой & 7 & 0,9 & 0 & 0 \\
\hline Фomoannapam & 7 & 0,9 & 0 & 0 \\
\hline Instagram & 6 & 0,8 & 0 & 0 \\
\hline Приложение & 5 & 0,6 & 0 & 0 \\
\hline Реклама & 5 & 0,6 & 2 & 0,6 \\
\hline Котики & 5 & 0,6 & 0 & 0 \\
\hline Лайк & 5 & 0,6 & 4 & 1,2 \\
\hline Хрень & 5 & 0,6 & 0 & 0 \\
\hline Понтьл & 4 & 0,5 & 0 & 0 \\
\hline Говно & 4 & 0,5 & 0 & 0 \\
\hline Альбом & 4 & 0,5 & 0 & 0 \\
\hline Лента & 4 & 0,5 & 4 & 1,2 \\
\hline Трата времени & 4 & 0,5 & 0 & 0 \\
\hline Фильтры & 4 & 0,5 & 0 & 0 \\
\hline Галерея & 3 & 0,4 & 0 & 0 \\
\hline Видео & 3 & 0,4 & 0 & 0 \\
\hline Гламур & 3 & 0,4 & 0 & 0 \\
\hline Полароид & 3 & 0,4 & 0 & 0 \\
\hline Истории & 3 & 0,4 & 2 & 0,6 \\
\hline Показуха & 3 & 0,4 & 60 & 18,2 \\
\hline Пафос & 3 & 0,4 & 0 & 0 \\
\hline Не пользуюсь & 3 & 0,4 & 0 & 0 \\
\hline Хипстеры & 3 & 0,4 & 0 & 0 \\
\hline Xaün & 3 & 0,4 & 0 & 0 \\
\hline Пора на пенсию & 0 & 0 & 25 & 7,6 \\
\hline Друзья & 0 & 0 & 3 & 0,9 \\
\hline Торговля & 0 & 0 & 2 & 0,6 \\
\hline Эстетика & 0 & 0 & 2 & 0,6 \\
\hline Блог, блогер & 0 & 0 & 4 & 1,2 \\
\hline Глупость & 0 & 0 & 6 & 1,8 \\
\hline Развлечение & 0 & 0 & 4 & 1,2 \\
\hline Иконка Инстаграма & 0 & 0 & 2 & 0,6 \\
\hline Общение & 0 & 0 & 2 & 0,6 \\
\hline Популярность & 0 & 0 & 2 & 0,6 \\
\hline Путешествия & 0 & 0 & 2 & 0,6 \\
\hline
\end{tabular}


Русскоязычные и украиноязычные респонденты в Украине дают реакции, отсутствующие у россиян (табл. 11): пора на пенсию, блог, блогер, популярность, путешествия, торговля, друзья и др. (Горошко \& Полякова, 2019), что позволяет говорить о социо- и культурспецифичности концепта.

Таблица 12. Полевая организация субконцепта Instagram/Инстаграм

\begin{tabular}{|c|c|c|}
\hline Уровень & Когнитивные признаки & $\begin{array}{c}\text { Индекс } \\
\text { яркости (\%) }\end{array}$ \\
\hline Ядро & Фоmo & 38,7 \\
\hline Ближняя периферия & - & - \\
\hline Дальняя периферия & Картинки, соииальная сеть, еда, ТП, селфи, квадрат & 14,1 \\
\hline Крайняя периферия & $\begin{array}{l}\text { Губы уточкой, фотоаппарат, Instagram, приложение, } \\
\text { реклама, котики, лайк <...> }\end{array}$ & 47,2 \\
\hline
\end{tabular}

Ядро субконцепта Instagram/Инстаграм представлено признаком фото (38,7\%); ближняя периферия в текущем анализе отсутствует.

Таблица 13. Классификационные когнитивные признаки субконцепта Instagram/ Инстаграм

\begin{tabular}{|c|c|c|c|}
\hline $\begin{array}{c}\text { Когнитивный } \\
\text { признак }\end{array}$ & Вербальная репрезентация & $\begin{array}{c}\text { Количество } \\
\text { реакций }\end{array}$ & $\begin{array}{c}\text { Индекс } \\
\text { яркости (\%) }\end{array}$ \\
\hline Контент & $\begin{array}{l}\text { фото, картинки, еда, селфи, губы уточкой, } \\
\text { котики, альбом, галерея, видео, истории, } \\
\text { хэштег, себяшки, жопь, селфи с котом, } \\
\text { картинки, и пафосно покушать, <...>. }\end{array}$ & 430 & 54,9 \\
\hline $\begin{array}{l}\text { Негативная } \\
\text { оценка }\end{array}$ & $\begin{array}{l}\text { ТП, хрень, понтыл, говно, трата времени, } \\
\text { показуха, пафос, хайп, хлам, утка, спам, } \\
\text { нарииссизм, надоел, жопь, глупость, ад, } \\
\text { ерунда, <..>. }\end{array}$ & 115 & 14,7 \\
\hline Пользователи & $\begin{array}{l}\text { дуры, подруга, ТП, молодые девушки, } \\
\text { хипстер, сборище баб, фотки баб, люди с } \\
\text { «инстаграмом головного мозга», куча тупьх } \\
\text { людей, <..>. }\end{array}$ & 41 & 5,2 \\
\hline Интерфейс & $\begin{array}{l}\text { квадрат, лайк, лента, фильтры, истории, } \\
\text { иконка, бельій фон, ирифт с завитушками, } \\
\text { объектив, логотип Instagram, фотографии } \\
1: 1,<\ldots>\text {. }\end{array}$ & 37 & 4,7 \\
\hline $\begin{array}{l}\text { Социальная } \\
\text { сеть }\end{array}$ & $\begin{array}{l}\text { Социальная сеть, Instagram, тумблр, twitter, } \\
\text { вк, фейсбук }\end{array}$ & 35 & 4,5 \\
\hline
\end{tabular}


Social Media in English and Russian Language Consciousness...

\begin{tabular}{|c|c|c|c|}
\hline Использование & $\begin{array}{l}\text { не пользуюсь, раскрутка, реклама, } \\
\text { фотографировать еду, хранилище фото, } \\
\text { средство узнавания новостей о близких и } \\
\text { друзьях, залипла, <...>. }\end{array}$ & 26 & 3,3 \\
\hline $\begin{array}{l}\text { Позитивная } \\
\text { оценка }\end{array}$ & $\begin{array}{l}\text { эстетика, красота, модно, средство } \\
\text { узнавания новостей о близких и друзьях, } \\
\text { красиво, полезно, норм, творчество, } \\
\text { искусство, лавки и симпь, breakthrough, } \\
\text { идеи, смешные видео }\end{array}$ & 14 & 1,8 \\
\hline $\begin{array}{l}\text { Название } \\
\text { Instagram }\end{array}$ & $\begin{array}{l}\text { Instagram, грамм, в } 100 \text { грамм, фифограм, } \\
\text { грамматика, insta gram, dvestigramm. }\end{array}$ & 11 & 1,4 \\
\hline Приложение & $\begin{array}{l}\text { приложение, } \quad \text { webpack, } \\
\text { платформа, приложение, прога }\end{array}$ & 9 & 1,1 \\
\hline
\end{tabular}

Наибольшей яркостью обладает классификационный признак контент $(54,9 \%)$, что объясняется спецификой самой социальной сети: изначально она была ориентирована исключительно на публикацию контента; функция мессенджера в ней появилась значительно позднее.

2.2. Субконцепт Instagram. Когнитивные признаки, полевая организация и когнитивные классификаторы субконцепта Instagram представлены в таблицах 14-16.

Таблица 14. Когнитивные признаки в субконцепте Instagram

\begin{tabular}{lcclcc}
\hline $\begin{array}{l}\text { Когнитивный } \\
\text { признак }\end{array}$ & $\begin{array}{c}\text { Количество } \\
\text { реакций }\end{array}$ & $\begin{array}{c}\text { Индекс } \\
\text { яркости (\%) }\end{array}$ & $\begin{array}{c}\text { Когнитивный } \\
\text { признак }\end{array}$ & $\begin{array}{c}\text { Количество } \\
\text { реакций }\end{array}$ & $\begin{array}{c}\text { Индекс } \\
\text { яркости (\%) }\end{array}$ \\
\hline picture & 26 & $\mathbf{1 8 , 8}$ & hastags & 1 & 0,7 \\
photo & 23 & $\mathbf{1 6 , 7}$ & Luke & 1 & 0,7 \\
filter & 6 & 4,3 & undo-able liking & 1 & 0,7 \\
social & 5 & 3,6 & hoes & 1 & 0,7 \\
food & 3 & 2,2 & gram & 1 & 0,7 \\
follower & 2 & 1,4 & pictures filters & 1 & 0,7 \\
like & 2 & 1,4 & followers & 1 & 0,7 \\
media & 2 & 1,4 & photography & 1 & 0,7 \\
& & & social platform & & \\
meme & 2 & 1,4 & family & 1 & 0,7 \\
more & 2 & 1,4 & photos people & 1 & 0,7 \\
pic & 2 & 1,4 & things food & & 0,7 \\
\hline
\end{tabular}


Социальные медиа в английском и русском языковом сознании...

\begin{tabular}{|c|c|c|c|c|c|}
\hline sharing & 2 & 1,4 & body image & 1 & 0,7 \\
\hline Telegram & 2 & 1,4 & snap & 1 & 0,7 \\
\hline Twitter & 2 & 1,4 & notifications & 1 & 0,7 \\
\hline selfie & 2 & 1,4 & advertising & 1 & 0,7 \\
\hline social media & 2 & 1,4 & cats & 1 & 0,7 \\
\hline screen & 1 & 0,7 & artsy & 1 & 0,7 \\
\hline $\begin{array}{l}\text { pictures of } \\
\text { where I take my } \\
\text { cellphone }\end{array}$ & 1 & 0,7 & likes & 1 & 0,7 \\
\hline $\begin{array}{l}\text { picture-based } \\
\text { social network }\end{array}$ & 1 & 0,7 & $\begin{array}{l}\text { people showing } \\
\text { off }\end{array}$ & 1 & 0,7 \\
\hline duck face & 1 & 0,7 & photos & 1 & 0,7 \\
\hline blondes & 1 & 0,7 & celebs & 1 & 0,7 \\
\hline pornography & 1 & 0,7 & recipes & 1 & 0,7 \\
\hline socialising & 1 & 0,7 & app & 1 & 0,7 \\
\hline message & 1 & 0,7 & sponsored & 1 & 0,7 \\
\hline $\begin{array}{l}\text { pretentious } \\
\text { gourmets }\end{array}$ & 1 & 0,7 & popular & 1 & 0,7 \\
\hline collage & 1 & 0,7 & gray & 1 & 0,7 \\
\hline memes & 1 & 0,7 & «models» & 1 & 0,7 \\
\hline son & 1 & 0,7 & $\begin{array}{l}\text { desperate for } \\
\text { attention / } \\
\text { validation }\end{array}$ & 1 & 0,7 \\
\hline friend & 1 & 0,7 & connection & 1 & 0,7 \\
\hline scrolling & 1 & 0,7 & fashion & 1 & 0,7 \\
\hline writing & 1 & 0,7 & social & 1 & 0,7 \\
\hline lame pictures & 1 & 0,7 & $\begin{array}{l}\text { gets more and } \\
\text { more fake }\end{array}$ & 1 & 0,7 \\
\hline life & 1 & 0,7 & sadness & 1 & 0,7 \\
\hline pointless & 1 & 0,7 & friendship & 1 & 0,7 \\
\hline new trend & 1 & 0,7 & & & \\
\hline
\end{tabular}

Таблица 15. Полевая организация субконцепта Instagram

\begin{tabular}{llc}
\hline \multicolumn{1}{c}{ Уровень } & \multicolumn{1}{c}{ Когнитивные признаки } & Яркость, \% \\
\hline Ядро & Picture, photo & 35,5 \\
Ближняя периферия & - & \\
Дальняя периферия & Filter, social, food & 10,1 \\
Крайняя периферия & $\begin{array}{l}\text { Follower, like, media, meme, more, pic, sharing, } \\
\text { Telegram, Twitter, <...>. }\end{array}$ & 54,4 \\
\hline
\end{tabular}


Таблица 16. Классификационные когнитивные признаки субконцепта Instagram

\begin{tabular}{|c|c|c|}
\hline Классификатор & Когнитивные признаки & Яркость, \% \\
\hline Content & $\begin{array}{l}\text { picture, photo, food, meme, pic, advertising, blonde, body, } \\
\text { cat, collage, duck, face, fashion, gourmet, hastag, image, } \\
\text { photography, picture-base, pornography, recipe, selfie, selfy }\end{array}$ & 52,9 \\
\hline People & $\begin{array}{l}\text { social, follower, blonde, celeb, family, friend, friendship, } \\
\text { hoe, «models», sister, socialising, son }\end{array}$ & 12,3 \\
\hline $\begin{array}{l}\text { Evaluation } \\
\text { (negative) }\end{array}$ & $\begin{array}{l}\text { duck face, pornography, pretentious gourmets, lame } \\
\text { pictures, pointless, undo-able liking, hoes, artsy, people } \\
\text { showing off, «models», desperate for attention/validation, } \\
\text { gets more and more fake, sadness }\end{array}$ & 9,4 \\
\hline Platform & $\begin{array}{l}\text { social, media, social media, Picture-Based Social Network, } \\
\text { gram, Photography social platform sharing, app }\end{array}$ & 9,4 \\
\hline Interface & filter, like, notification, validation & 7,2 \\
\hline Social networks & twitter, tumblr & 2,9 \\
\hline $\begin{array}{l}\text { Evaluation } \\
\text { (positive) }\end{array}$ & trend, trendy & 1,4 \\
\hline
\end{tabular}

В англоязычных и русскоязычных данных в России и в Украине очевидно преобладание общих негативных признаков (табл. 17), однако российские пользователи дают более разнообразные пейоративные оценки.

Таблица 17. Негативная оценка субконцепта Инстаграм/Instagram

\begin{tabular}{|c|c|c|c|}
\hline \multirow[t]{2}{*}{$\begin{array}{c}\text { Когнитивный } \\
\text { классификатор }\end{array}$} & \multicolumn{2}{|c|}{ Наши данные, 2017-2018 (Россия) } & \multirow{2}{*}{$\begin{array}{c}\text { Данные } \\
\text { E. Горошко и } \\
\text { T. Поляковой, } \\
2019 \text { (Украина) } \\
\text { русский язык }\end{array}$} \\
\hline & английский язык & русский язык & \\
\hline \multirow[t]{2}{*}{ Глупость } & desperate for & с «инстаграмом & глупость \\
\hline & attention/validation & $\begin{array}{l}\text { головного мозга», куча тупьх } \\
\text { людей, долбоебы, идиоты, } \\
\text { глупье люди, тупить }\end{array}$ & \\
\hline Глупые женщины & «models», hoes & $\begin{array}{l}\text { ТП, дуры, куча тупьх тёлок, } \\
\text { бабы тупье, телки, некая } \\
\text { ванильная чика, курицьь, бабы } \\
\text { тупье }\end{array}$ & \\
\hline $\begin{array}{l}\text { Девушки с низкой } \\
\text { социальной } \\
\text { ответственностью }\end{array}$ & pornography & чика, бл..ский ицирк & \\
\hline $\begin{array}{l}\text { Бесполезность, } \\
\text { малозначительность }\end{array}$ & $\begin{array}{l}\text { pointless, undo-able } \\
\text { liking }\end{array}$ & $\begin{array}{l}\text { хрень, трата времени, хлам, } \\
\text { ерунда, бессмысленность, } \\
\text { бесполезно, низачем }\end{array}$ & пора на пенсию \\
\hline
\end{tabular}


Социальные медиа в английском и русском языковом сознании...

\begin{tabular}{|c|c|c|c|}
\hline Фальшивость & $\begin{array}{l}\text { gets more and more } \\
\text { fake, pretentious } \\
\text { gourmets, artsy, } \\
\text { people showing off }\end{array}$ & $\begin{array}{l}\text { понты, показуха, пафос, хайп, } \\
\text { ярмарка тщеславия, понты, } \\
\text { силиконовые губы, излишнее } \\
\text { хвастовство }\end{array}$ & показуха \\
\hline Ягодицы & ass & $\begin{array}{l}\text { жопьl, головожопость, } \\
\text { женские жопьl, фотожоп }\end{array}$ & \\
\hline $\begin{array}{l}\text { Человеческие } \\
\text { отправления, мусор }\end{array}$ & & $\begin{array}{ll}\text { говно, } & \text { опорожнение } \\
\text { общества, кал }\end{array}$ & помойка \\
\hline Утиное лицо & duck face & губьл уточкой & \\
\hline $\begin{array}{l}\text { Типовые } \\
\text { фотографии }\end{array}$ & lame pictures, & $\begin{array}{l}\text { одинаковые фото девушек, } \\
\text { куча однотипных и } \\
\text { бессмысленных фото }\end{array}$ & \\
\hline Негативные эмоции & sadness & $\begin{array}{l}\text { раздражение, } \quad \text { }, \quad \text { уньлл, } \\
\text { грусть }\end{array}$ & $\begin{array}{l}\text { обман, } \\
\text { зависимость, } \\
\text { зависть }\end{array}$ \\
\hline
\end{tabular}

\section{3. Эксперименты 1-4: когнитивная интерпретация}

3.1. Концепт социальные медиa/social media. Ядро структуры (табл. 18) концепта социальныле медиа (с учетом данных по субконцептам) представлено признаком общение (коммуникащия) $(15,2 \%)$. Ближнюю периферию составляют признаки социальные сети, мессенджеры $(10,7 \%)$, негативная оценка $(10,4 \%)$, интерфейс (фирменный стиль) (9,4\%). Признаки люди (пользователи) (6,3\%) и контент, информачия (3,6\%) входят в дальнюю периферию. Крайняя периферия представлена признаками позитивная оценка (1,3\%), устройства $(1,0 \%)$.

Таблица 18. Классификационные когнитивные признаки концепта социальныле медиа: эксперименты 1-4 (индекс яркости, \%)

\begin{tabular}{|c|c|c|c|c|c|c|c|c|c|c|}
\hline $\operatorname{lac}$ & 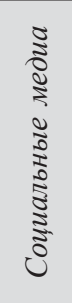 & 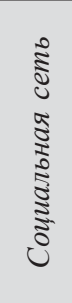 & 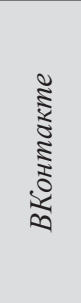 & 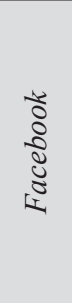 & 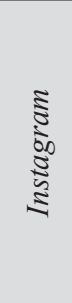 & 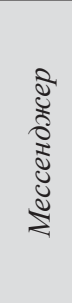 & 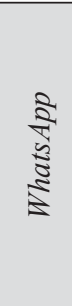 & $\begin{array}{l}\bar{\Xi} \\
\vdots\end{array}$ & 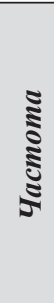 & 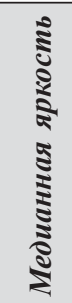 \\
\hline Общение (коммуникация) & 16,6 & 13,8 & 10,7 & 0 & 0 & 1 & 23,4 & 20 & 6 & 15,2 \\
\hline Социальные сети, мессенджеры & 6,1 & 38,2 & 15,2 & 19,2 & 4,5 & 33,1 & 4,8 & 5 , & 8 & 10,7 \\
\hline Негативная оценка & 3,2 & 10,8 & 0,2 & 11,3 & 14,7 & 5 & , & $11, J$ & o & 10,4 \\
\hline Интерфейс (фирменный стиль) & 0 & 1,1 & 14,7 & 15 & 4,7 & 3,4 & 14 & 20,3 & 7 & 9,4 \\
\hline Люди (пользователи) & 22,9 & 7,1 & 6,5 & 6,1 & 5,2 & 0 & 5,2 & 8,1 & 7 & 6,3 \\
\hline
\end{tabular}


Social Media in English and Russian Language Consciousness...

\begin{tabular}{lcccccccccc}
\hline Контент (информация) & 21,9 & 5 & 16 & 2,2 & 54,9 & 0 & 0 & 0 & 5 & $\mathbf{3 , 6}$ \\
Платформа (ресурс, приложение) & 9,7 & 0 & 0 & 0 & 1,1 & 2,3 & 30 & 22,7 & 5 & $\mathbf{1 , 7}$ \\
Позитивная оценка & 0,4 & 0,6 & 1,1 & 2,3 & 1,8 & 1,3 & 1,9 & 1,3 & 8 & $\mathbf{1 , 3}$ \\
Устройства & 0 & 2 & 0 & 0 & 0 & 5,2 & 5,6 & 3,6 & 4 & $\mathbf{1 , 0}$ \\
Интернет & 5,9 & 0 & 4,2 & 0 & 0 & 0 & 0 & 0 & 2 & 0,0 \\
Медиа & 7,6 & 0 & 0 & 0 & 0 & 0 & 0 & 0 & 1 & 0,0 \\
Социальная сеть как место & 0 & 6,5 & 0 & 0 & 0 & 0 & 0 & 0 & 1 & 0,0 \\
Название Viber & 0 & 0 & 0 & 0 & 0 & 0 & 0 & 6,4 & 1 & 0,0 \\
География & 0 & 0 & 0 & 5 & 0 & 0 & 0 & 0 & 1 & 0,0 \\
Название WhatsАрр & 0 & 0 & 0 & 0 & 0 & 0 & 5 & 0 & 1 & 0,0 \\
Использование & 0 & 0 & 0 & 0 & 3,3 & 0 & 0 & 0 & 1 & 0,0 \\
Быстрота коммуникации & 0 & 0 & 0 & 0 & 0 & 2,3 & 0 & 0 & 1 & 0,0 \\
Основатели социальных сетей & 0 & 2 & 0 & 0 & 0 & 0 & 0 & 0 & 1 & 0,0 \\
Помощь & 1,8 & 0 & 0 & 0 & 0 & 0 & 0 & 0 & 1 & 0,0 \\
Название Instagram & 0 & 0 & 0 & 0 & 1,4 & 0 & 0 & 0 & 1 & 0,0 \\
Развлечение & 1,1 & 0 & 0 & 0 & 0 & 0 & 0 & 0 & 1 & 0,0 \\
Работа & 0,9 & 0 & 0 & 0 & 0 & 0 & 0 & 0 & 1 & 0,0 \\
Интерес & 0,7 & 0 & 0 & 0 & 0 & 0 & 0 & 0 & 1 & 0,0 \\
Сообщества & 0,7 & 0 & 0 & 0 & 0 & 0 & 0 & 0 & 1 & 0,0 \\
Блоги & 0,6 & 0 & 0 & 0 & 0 & 0 & 0 & 0 & 1 & 0,0 \\
\hline
\end{tabular}

Ядро структуры (табл. 19) концепта social media (с учетом данных по субконцептам) представлено признаком connection and communication $(13,7 \%)$, в околоядерную зону входят признаки content $(10,3 \%)$ и people $(9,6 \%)$. Значимыми являются признак social media (2,9\%), репрезентирующий отдельные элементы, входящие в одноимённую категорию, и оценка с преобладанием негатива $(5,9 \%$ против $0,8 \%$ позитивных).

Таблица 19. Классификационные когнитивные признаки концепта social media: эксперименты 1-4 (индекс яркости, \%)

\begin{tabular}{|c|c|c|c|c|c|c|c|c|c|}
\hline субкон & 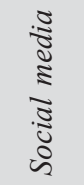 & 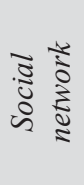 & 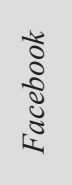 & 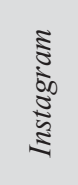 & 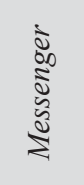 & 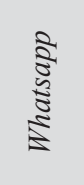 & $\frac{\grave{\Xi}}{\vdots}$ & 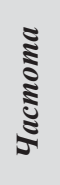 & 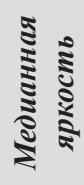 \\
\hline Connection and communication & 13,7 & 4,8 & 0 & 0 & 26,0 & 27,1 & 19,0 & 5 & 13,7 \\
\hline Content & 4,2 & 4,0 & 13,1 & 52,9 & 12,2 & 7,6 & 10,3 & 7 & 10,3 \\
\hline People & 9,6 & 7,9 & 29,0 & 12,3 & 0 & 13,6 & 0 & 5 & 9,6 \\
\hline
\end{tabular}


Социальные медиа в английском и русском языковом сознании...

\begin{tabular}{lccccccccc}
\hline Evaluation (negative) & 2,4 & 7,9 & 0 & 9,4 & 8,7 & 5,9 & 0 & 6 & $\mathbf{5 , 9}$ \\
Social media & 0 & 58,7 & 13,7 & 2,9 & 27,6 & 0 & 0 & 4 & $\mathbf{2 , 9}$ \\
Evaluation (positive) & 2,6 & 0,8 & 0 & 1,4 & 0,8 & 2,5 & 0 & 6 & $\mathbf{0 , 8}$ \\
Name (Viber) & 0 & 0 & 0 & 0 & 0 & 0 & 24,1 & 1 & 0 \\
Delivery & 0 & 0 & 0 & 0 & 14,2 & 0 & 0 & 1 & 0 \\
Platform & 10 & 0 & 0 & 9,4 & 0 & 0 & 0 & 2 & 0 \\
Mobile & 0 & 0 & 0 & 0 & 2,4 & 9,3 & 12,1 & 3 & 0 \\
Sex & 0 & 0 & 0 & 0 & 0 & 0 & 8,6 & 1 & 0 \\
Intrerface & 0 & 0 & 13,7 & 7,2 & 0 & 8,5 & 0 & 3 & 0 \\
Interaction & 0 & 0 & 8,4 & 0 & 0 & 0 & 0 & 1 & 0 \\
Religion and mythology & 0 & 0 & 0 & 0 & 5,5 & 0 & 0 & 1 & 0 \\
Snake & 0 & 0 & 0 & 0 & 0 & 0 & 5,2 & 1 & 0 \\
Geography & 0 & 0 & 0 & 0 & 0 & 5,1 & 0 & 1 & 0 \\
Internet & 6 & 4 & 0 & 0 & 0 & 0 & 0 & 2 & 0 \\
Name (WhatsApp) & 0 & 0 & 0 & 0 & 0 & 3,4 & 0 & 1 & 0 \\
Movie & 0 & 3,2 & 0 & 0 & 0 & 0 & 0 & 1 & 0 \\
Mark Zuckerberg & 0 & 0 & 3,1 & 0 & 0 & 0 & 0 & 1 & 0 \\
\hline
\end{tabular}

\section{2. Концепт социальные медиа/social media: сравнительный} анализ. Сопоставим полевую организацию субконцептов, полученную в ходе экспериментов 1-4 (табл. 20).

Таблица 20. Полевая организация субконцептов соичильные медиa/social media: эксперименты 1-4

\begin{tabular}{|c|c|c|c|}
\hline субконцепт & Ядро & Ближняя периферия & Дальняя периферия \\
\hline $\begin{array}{l}\text { Социальные } \\
\text { медиа }\end{array}$ & $\begin{array}{l}\text { социальный, } \\
\text { коммуникация, } \\
\text { информация }\end{array}$ & $\begin{array}{l}\text { люди, социальные сети, } \\
\text { интернет, } \\
\text { аудитория, } \\
\text { массововая } \\
\text { медиа, новедства } \\
\text { негативная информации, } \\
\text { р а с п р о с т р а н е н и ент, } \\
\text { информации }\end{array}$ & $\begin{array}{lr}\text { связь, способ, } & \text { ресурс, } \\
\text { видео, } & \text { пользователи, } \\
\text { помощь, } & \text { аудио, } \\
\text { в з а и м о д е й с т в и е }, \\
\text { изображения, } \\
\text { развлечение, планформа, } \\
\text { площадки, } \\
\text { реклама, приложения }\end{array}$ \\
\hline Social media & connect & $\begin{array}{l}\text { friend, platform, share, } \\
\text { online }\end{array}$ & $\begin{array}{l}\text { life, family, place, social, } \\
\text { website, interact, internet, } \\
\text { network, use }\end{array}$ \\
\hline Социальная сеть & ВКонтакте & $\begin{array}{l}\text { общение, } \\
\text { Facebook }\end{array}$ & $\begin{array}{l}\text { друзья, фильм, общество, } \\
\text { помойка, информация, } \\
\text { опасность, зависимость, } \\
\text { паутина, связь, Цукерберг }\end{array}$ \\
\hline
\end{tabular}




\begin{tabular}{|c|c|c|c|}
\hline Social network & Facebook & - & $\begin{array}{l}\text { friend, Twitter, Instagram, } \\
\text { movie, Reddit, boring, } \\
\text { connection, internet, media, } \\
\text { phone, Zuckerberg }\end{array}$ \\
\hline Facebook (pycc.) & сеть & $\begin{array}{l}\text { Цукерберг, } \\
\text { синий }\end{array}$ & $\begin{array}{lr}\text { соцсеть, } & \text { ВКонтакте, } \\
\text { Марк, } & \text { друзья, } \\
\text { иностранцы, } & \text { неудобный, } \\
\text { английский, новость, сайт }\end{array}$ \\
\hline Facebook (англ.) & friends & social, media & $\begin{array}{l}\text { blue, like, status, Twitter, } \\
\text { network, time }\end{array}$ \\
\hline Instagram (pycc.) & фото & - & $\begin{array}{l}\text { Картинки, социальная } \\
\text { сеть, еда, ТП, селфи, } \\
\text { квадрат }\end{array}$ \\
\hline Instagram (англ.) & picture, photo & - & filter, social, food \\
\hline Мессенджер & Телеграм & сообщение, WhatsApp & 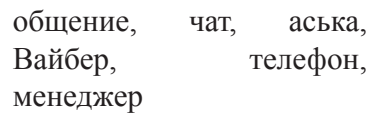 \\
\hline Messenger & Facebook & $\begin{array}{l}\text { bag, chat, message, text, } \\
\text { letter }\end{array}$ & $\begin{array}{l}\text { app, MSN, aim, AOL, } \\
\text { bike, contact, friend, god, } \\
\text { instant, Skype, Whatsapp, } \\
\text { wing, email, pidgeon }\end{array}$ \\
\hline WhatsApp (pycc.) & мессенджер & $\begin{array}{l}\text { зелёный, } \\
\text { приложение }\end{array}$ & $\begin{array}{l}\text { телефон, общение, чат, } \\
\text { Viber, социальная сеть, } \\
\text { трубка, зелёная иконка }\end{array}$ \\
\hline WhatsApp (англ.) & $\begin{array}{l}\text { messenger, chat, } \\
\text { friends, green, } \\
\text { phone, message }\end{array}$ & texting, text, app & $\begin{array}{l}\text { me, foreign, group, } \\
\text { communication, Facebook, } \\
\text { what, phones, social }\end{array}$ \\
\hline Viber (pycc.) & $\begin{array}{l}\text { мессенджер, } \\
\text { фиолетовый }\end{array}$ & $\begin{array}{l}\text { звонок, } \\
\text { приложение }\end{array}$ & $\begin{array}{l}\text { телефон, общение, Скайп, } \\
\text { связь, чат, вибрация, } \\
\text { мама, вибратор }\end{array}$ \\
\hline Viber (англ.) & messenger, text & $\begin{array}{l}\text { snake, chat, vibe, app, } \\
\text { buzz, vines, cell, phone, } \\
\text { calls }\end{array}$ & $\begin{array}{l}\text { ator, communicate, } \\
\text { communication, confused, } \\
\text { free, good }\end{array}$ \\
\hline ВКонтакте & сеть & $\begin{array}{l}\text { синий, } \\
\text { Дуров }\end{array}$ & $\begin{array}{l}\text { музыка, друзья, общение, } \\
\text { новость, сообщение, сайт, } \\
\text { соцсеть, собака }\end{array}$ \\
\hline
\end{tabular}

- Полевая организация концептов социальные медиа и social media различается как на уровне ядра, так и на уровне ближней периферии.

- Признаки, тяготеющие к ядру концепта социальные медиа, входят в периферию концепта social media. Наблюдается и обратная динамика. 
- Ядро субконцептов сочиильная сеть и social network организовано идентично: представлено признаками, актуализирующими их прототипы (ВКонтакте для субкатегории социальная cemb, Facebook - для social network).

- Ядро субконцепта Facebook в русскоязычном дискурсе представлено признаком сеть (отсылка к его принадлежности субкатегории социальная сеть), в англоязычном дискурсе признаком friends (возможно, большая сформированность субконцепта у англоязычных пользователей).

- Полевая организация субконцепта Instagram практически идентична для русско- и англоязычных дискурсов на всех уровнях, что, вероятнее всего, является результатом аналогичного пользовательского опыта.

- Ядро субконцептов мессенджер/messenger идентично, однако в качестве репрезентанта (возможно, прототипа) в русскоязычном эксперименте служит Telegram, в англоязычном - Facebook (имеется в виду Facebook Messenger). В англоязычном эксперименте эксплицируется больше элементов субкатегории messenger.

- Субконцепт WhatsApp идентичен по результатам обоих экспериментов, однако ядро в русскоязычном дискурсе выглядит более сформированным, чем в англоязычном. Возможно, это связано с более высокой популярностью WhatsApp в русскоязычных странах (в США, Канаде, Австралии более популярен Facebook Messenger).

- Полевая организация субконцепта Viber аналогична организации субконцепта WhatsApp: более размытое ядро в англоязычном дискурсе и более высокая степень сформированности в русскоязычном.

Представим к сравнению обобщённые перечни классификационных признаков концептов социальные медиа и social media, полученные в ходе экспериментов 1-4 (табл. 21).

Содержательно пересекаются все возможные признаки (сочиальные сети, мессенджеры - social media, интерфейс (фирменньй стиль) - intrerface, люди (пользователи) - реорle, контент (информация) - content, негативная оценка - evaluation (negative), позитивная оценка - evaluation (positive) (табл. 21). 
Таблица 21. Классификационные когнитивные признаки концептов социальныле медиа и social media

\begin{tabular}{|c|c|c|c|}
\hline Социальные медиа & $\begin{array}{c}\text { Медианая } \\
\text { яркость, \% }\end{array}$ & Social media & $\begin{array}{l}\text { Медианная } \\
\text { яркость, \% }\end{array}$ \\
\hline Общение (коммуникация) & 15,2 & $\begin{array}{l}\text { Connection and } \\
\text { communication }\end{array}$ & 13,7 \\
\hline Социальные сети, мессенджеры & 10,7 & Content & 10,3 \\
\hline Негативная оценка & 10,4 & People & 9,6 \\
\hline Интерфейс (фирменный стиль) & 9,4 & Evaluation (negative) & 5,9 \\
\hline Люди (пользователи) & 6,3 & Social media & 2,9 \\
\hline Контент (информация) & 3,6 & Evaluation (positive) & 0,8 \\
\hline Платформа (ресурс, приложение) & 1,7 & & \\
\hline Позитивная оценка & 1,3 & & \\
\hline Устройства & 1,0 & & \\
\hline
\end{tabular}

Однако количественно значимых для категории coųuальные медиа признаков больше на треть, чем значимых признаков категории social media, что может быть обусловлено большим количеством респондентов в русскоязычном эксперименте.

Достоверность различий между значениями в двух выборках при помощи углового преобразования Фишера (критерий $\varphi$ ) представлена в таблице 22.

Таблица 22. Угловое преобразование Фишера для парных признаков концептов социальные медиа/social media

\begin{tabular}{lcl}
\hline \multicolumn{1}{c}{ Пара признаков } & $\boldsymbol{\varphi}^{*}$ эмп & \multicolumn{1}{c}{ Значимость } \\
\hline $\begin{array}{l}\text { Общение (коммуникация)/connection } \\
\text { and communication }\end{array}$ & 0,491 & незначимо \\
Социальные сети, мессенджеры / social media & 4,145 & значимо \\
Люди (пользователи) / people & 1,506 & незначимо \\
Контент (информация) / content & 3,566 & значимо \\
Негативная оценка / evaluation (negative) & 2,168 & зона неопределенности \\
Позитивная оценка / evaluation (positive) & 0,34 & незначимо \\
\hline
\end{tabular}

Значимы различия в яркости только двух пар признаков: социиальные сети, мессенджеры/social media, контент (информация)/ content. Значение $\varphi^{*}$ эмп для признаков негативная оценка/evaluation (negative) попадает в зону неопределённости $\left(\mathrm{H}_{0}\right.$ отвергается, $\mathrm{H}_{1}$ не подтверждается). 


\section{Выводы}

С учётом определённой институализации социальных медиа в современном обществе концепт социальные медиа, с одной стороны, можно отнести к базовым социальным концептам: коммуникация, занятия (формирование блогерства как профессии и средства заработка), власти и управления (так называемые твиттерреволюции), интерперсональные отношения. С другой стороны, концепт социальные медиа можно отнести к концептам-релятивам, которые отражают опыт социального взаимодействия пользователей и содержат значительное число оценочных предикатов в номинативном поле. Данная нечеткость определения исследуемого нами явления отражает тезис о размытых и условных границах концепта, его «полиаппелируемости» и «многомерности».

Концепт социальные медиа/social media относится к категориальному типу и включает в себя неопределённое множество элементов. Концепт социальные медиа среди прочих включает субконцепты соииальная cemb, BКонтакте, Facebook/ Фейсбук, Instagram/Истаграм, Twitter/Tвиттер, мессенджер, WhatsApp/Bamcan, Viber/Baйбер. Концепт social media включает субконцепты social network, Facebook, Twitter, Instagram, messenger, WhatsApp, Viber.

Универсальными чертами концепта социальные медиа/social media в русском и английском дискурсах являются: (1) идентичная когнитивно-классификационная структура, различия проявляются только на периферии; (2) ряд когнитивных признаков: общение/ communication, друзья/friends, информаџия/information, мессенджер/ messenger, интернет/internet и др.

Социо- и культурспецифическими чертами концепта couииальные медиа/social media в русском и английском дискурсах являются: (1) концепт couиальные медиa/social media обладает большей сформированностью в англоязычной лингвокультуре: семантика номинаций, входящих в номинативное поле концепта репрезентирует личные, близкие контакты (friend, life, family), тогда как в русском языке - отстранённое, неличное представление о социальных медиа (коммуникация, массовая аудитория, пользователи); (2) ядро концепта соичальные медиа/social media в русском и английском дискурсах составляют разные 
Social Media in English and Russian Language Consciousness...

когнитивные признаки; общее присутствует только на периферии номинативного поля.

Результаты исследования могут быть полезны в развитии психолингвистики 2.0, социолингвистики, компьютерной лингвистики (OCR, ASR, Data Mining, информационный поиск, реферирование текстов, машинный перевод и пр.), лексикографической практики, в том числе создании электронных словарей, тезаурусов, онтологий, двуязычных и ассоциативных словарей и пр.

\section{Литература}

Акімова, Н., \& Олександренко, К. (2019). Вплив досвіду користування інтернетом на особливості розуміння текстів інтернету. Psycholinguistics, 26 (1), 11-36. https://doi.org/10.31470/2309-1797-2019-26-1-11-36

Бабенко, М. (Ред.). (2018). Кониептосфера русского языка. Ключевые концепты и их репрезентации в языке и речи. Москва: Азбуковник.

Горошко, О., \& Полякова, Т. (2019). Освіта 2.0: психолінгвістичний аналіз. Psycholinguistics, 26 (2), 27-45. https://doi.org/10.31470/2309-1797-2019-26-2-27-45

Камінська, О., Стежко, Ю., \& Глєбова, Л. (2019). Психолінгвістика віртуальної комунікації в контексті залежності від соціальних мереж. Psycholinguistics, 25 (1), 147-164. https://doi.org/10.31470/2309-1797-2019-25-1-147-164

Клюев, Н.А. (2016а). Структура концепта «социальные сети» в русском языковом сознании. Master's Journal, 1, 479-484.

Клюев, Н.А. (2016b) Дуров vs. Цукерберг: «Вконтакте» и «Facebook» в русском языковом сознании. Социо- и психолингвистические исследования, 4, 98-104.

Клюев, Н.А. (2018а). Концепт социальные медиа в русском языковом сознании (по материалам анализа литературы и психолингвистического эксперимента). Litera, 3, 11-21. https://doi.org/10.25136/2409-8698.2018.3.26680

Клюев, Н.A. (2018b). Viber и WhatsApp в русском языковом сознании: анализ полевой и категориальной структуры. Филология: научные исследования, 3, 40-51. https://doi.org/10.7256/2454-0749.2018.3.26683

Попова, З.Д., \& Стернин, И.А. (2007). Понятие когнитивной интерпретации. Когнитивная лингвистика (с. 198-210). Москва: «Восток-Запад».

Храбан, Т. (2019). Психолингвистические аспекты визуальных компонентов интернет-мемов. Psycholinguistics, 26 (2), 341-357. https://doi. org/10.31470/2309-1797-2019-26-2-341-357

Шебанова, В., \& Яблонська, Т. (2019). Нікнейм як засіб мовної самопрезентації в Інтернеті осіб з порушеннями харчової поведінки. Psycholinguistics, 25 (1), 409-430. https://doi.org/10.31470/2309-1797-2019-25-1-409-430

Bail, C.A. et al. (2018). Exposure to opposing views on social media can increase political polarization. Pnas, 115 (37), 9216-9221. https://doi.org/10.1073/ pnas. 1804840115

Blank, G., \& Lutz, C. (2017). Representativeness of social media in Great Britain: Investigating Facebook, LinkedIn, Twitter, Pinterest, Google+, 
and Instagram. American Behavioral Scientist, 61, 741-756. https://doi. org/10.1177/0002764217717559

Chu, Z., Gianvecchio, S., Wang, H., \& Jajodia, S. (2012) Detecting automation of Twitter accounts: are you a human, bot, or cyborg? IEEE Trans Dependable Secur Comput, 9 (6), 811-824. https://doi.org/10.1109/TDSC.2012.75

Gilani, Z., Almeida, M., Farahbakhsh, R., Wang, L., \& Crowcroft, J. (2016). Stweeler: A framework for Twitter bot analysis. Proceedings of the 25th international conference companion on world wide web (pp. 37-38). Montréal, Canada. https:// doi.org/10.1145/2872518.2889360

Gilani, Z., Farahbakhsh, R., Tyson, G., Wang, L., \& Crowcroft, J. (2017). Of bots and humans (on Twitter). Proceedings of the 2017 IEEE/ACM international conference on advances in social networks analysis and mining (pp. 349-354). Sydney, Australia. https://doi.org/10.1145/3110025.3110090

Grimme, C., Assenmacher, D., \& Adam, L. (2018). Changing perspectives: Is it sufficient to detect social bots? In G. Meiselwitz (Ed.), Social computing and social media, user experience and behavior, SCSM 2018 lecture notes in computer science (pp. 445-461). Springer, Cham. https://doi.org/10.1007/978-3319-91521-0_32

Guo, L., Tan, E., Chen, S., Zhang, X., \& Zhao, Y. (2009). Analyzing patterns of user content generation in online social networks. Proceedings of the 15th ACM SIGKDD international conference on knowledge discovery and data mining (pp. 369-378). Paris, France. https://doi.org/10.1145/1557019.1557064

Hargittai, E. (2018). Potential Biases in Big Data: Omitted Voices on Social Media. Social Science Computer Review, 38 (1), 10-24. https://doi. org/10.1177/0894439318788322

Schmidt, A.L. et al. (2017). Anatomy of news consumption on Facebook. Pnas, 114 (12), 3035-3039. https://doi.org/10.1073/pnas.1617052114

Stine, Z.K., \& Agarwal, N. (2019). Characterizing the language-production dynamics of social media users. Soc. Netw. Anal. Min., 9, 60. https://doi.org/10.1007/ s13278-019-0605-7

Stine, Z.K., Khaund, T., \& Agarwal, N. (2018). Measuring the information-foraging behaviors of social bots through word usage. Proceedings of the IEEE/ACM international conference on advances in social networks analysis and mining (pp. 570-671). Barcelona, Spain. https://doi.org/10.1109/ASONAM.2018.8508811

Winata, C., \& Andangsari, E.W. (2017). Dispositional Gratitude and Social Comparison Orientation among Social Media Users. Humaniora, 8 (3), 229-237. https://doi.org/10.21512/humaniora.v8i3.3620

\section{References}

Akimova, N., \& Oleksandrenko, K. (2019). Vplyv dosvidu korystuvannia internetom na osoblyvosti rozuminnia tekstiv internetu [Impact of the Internet Using Experience on the Peculiarities of the Internet Texts Understanding]. Psykholinhvistyka - Psycholinguistics, 26 (1), 11-36. https://doi. org/10.31470/2309-1797-2019-26-1-11-36 [in Ukrainian].

Babenko, M. (Ed.). (2018). Konceptosfera russkogo jazyka. Kljuchevye koncepty $i$ ih reprezentacii $v$ jazyke $i$ rechi [The concept sphere of the Russian language. 
Key concepts and their representations in language and speech]. Moscow: Azbukovnik [in Russian].

Goroshko, O., \& Poliakova, T. (2019). Osvita 2.0: psykholinhvistychnyi analiz [Education 2.0: Psycholinguistic Analysis]. Psykholinhvistyka - Psycholinguistics, 26 (2), 27-45. https://doi.org/10.31470/2309-1797-2019-26-2-27-45 [in Ukrainian]. Kaminska, O., Stezhko, Y., \& Gliebova, L. (2019). Psykholinhvistyka virtualnoi komunikatsii $\mathrm{v}$ konteksti zalezhnosti vid sotsialnykh merezh [Psycholinguistics of Virtual Communication in the Context of the Dependence on Social Networks]. Psykholinhvistyka - Psycholinguistics, 25 (1), 147-164. https://doi. org/10.31470/2309-1797-2019-25-1-147-164 [in Ukrainian].

Klyuev, N.A. (2016a). Struktura koncepta «socialnye seti» v russkom jazykovom soznanii [Structure of the concept «social networks» in the Russian language consciousness]. Master's Journal, 1, 479-484 [in Russian].

Klyuev, N.A. (2016b). Durov vs. Czukerberg: «Vkontakte» i «Facebook» v russkom yazykovom soznanii [Durov vs. Zuckerberg: «Vkontakte» and «Facebook» in the Russian linguistic consciousness]. Socio- $i$ psixolingvisticheskie issledovaniya Socio- and psycholinguistic research, 4, 98-104 [in Russian].

Klyuev, N.A. (2018a). Koncept socialnye media v russkom jazykovom soznanii (po materialam analiza literatury i psiholingvisticheskogo jeksperimenta) [Social media concept in the Russian language consciousness (based on literature analysis and psycholinguistic experiment)]. Litera, 3, 11-21. https://doi. org/10.25136/2409-8698.2018.3.26680 [in Russian].

Klyuev, N.A. (2018b). Viber i WhatsApp v russkom jazykovom soznanii: analiz polevoj i kategorialnoj struktury [Viber and WhatsApp in Russian language consciousness: analysis of field and categorical structure]. Filologija: nauchnye issledovanija - Philology: scientific research, 3, 40-51. https://doi. org/10.7256/2454-0749.2018.3.26683 [in Russian].

Popova, Z.D., \& Sternin, I.A. (2007). Ponyatie kognitivnoj interpretacii [The Concept of cognitive interpretation]. Kognitivnaya lingvistika - Cognitive linguistics (pp. 198-210). Moscow: «Vostok-Zapad» [in Russian].

Khraban, T. (2019). Psiholingvisticheskie aspekty vizualnyh komponentov internetmemov [Psycholinguistic Aspects of the Internet Memes' Visual Components]. Psykholinhvistyka - Psycholinguistics, 26 (2), 341-357. https://doi. org/10.31470/2309-1797-2019-26-2-341-357 [in Russian].

Shebanova, V., \& Yablonska, T. (2019). Nikneim yak zasib movnoi samoprezentatsii $\mathrm{v}$ Interneti osib $\mathrm{z}$ porushenniamy kharchovoi povedinky [Nickname as a Means of Linguistic Self-Presentation in the Internet of People with Eating Disorders]. Psykholinhvistyka - Psycholinguistics, 25 (1), 409-430. https://doi. org/10.31470/2309-1797-2019-25-1-409-430 [in Ukrainian].

Bail, C.A. et al. (2018). Exposure to opposing views on social media can increase political polarization. Pnas, 115 (37), 9216-9221. https://doi.org/10.1073/ pnas. 1804840115

Blank, G., \& Lutz, C. (2017). Representativeness of social media in Great Britain: Investigating Facebook, LinkedIn, Twitter, Pinterest, Google+, and Instagram. American Behavioral Scientist, 61, 741-756. https://doi. org $/ 10.1177 / 0002764217717559$

Chu, Z., Gianvecchio, S., Wang, H., \& Jajodia, S. (2012) Detecting automation of Twitter accounts: are you a human, bot, or cyborg? IEEE Trans Dependable Secur Comput, 9 (6), 811-824. https://doi.org/10.1109/TDSC.2012.75 
Gilani, Z., Almeida, M., Farahbakhsh, R., Wang, L., \& Crowcroft, J. (2016). Stweeler: A framework for Twitter bot analysis. Proceedings of the 25th international conference companion on world wide web (pp. 37-38). Montréal, Canada. https:// doi.org/10.1145/2872518.2889360

Gilani, Z., Farahbakhsh, R., Tyson, G., Wang, L., \& Crowcroft, J. (2017). Of bots and humans (on Twitter). Proceedings of the 2017 IEEE/ACM international conference on advances in social networks analysis and mining (pp. 349-354). Sydney, Australia. https://doi.org/10.1145/3110025.3110090

Grimme, C., Assenmacher, D., \& Adam, L. (2018). Changing perspectives: Is it sufficient to detect social bots? In G. Meiselwitz (Ed.), Social computing and social media, user experience and behavior, SCSM 2018 lecture notes in computer science (pp. 445-461). Springer, Cham. https://doi.org/10.1007/978-3319-91521-0 32

Guo, L., Tan, E., Chen, S., Zhang, X., \& Zhao, Y. (2009). Analyzing patterns of user content generation in online social networks. Proceedings of the 15th ACM SIGKDD international conference on knowledge discovery and data mining (pp. 369-378). Paris, France. https://doi.org/10.1145/1557019.1557064

Hargittai, E. (2018). Potential Biases in Big Data: Omitted Voices on Social Media. Social Science Computer Review, 38 (1), 10-24. https://doi. org/10.1177/0894439318788322

Schmidt, A.L. et al. (2017). Anatomy of news consumption on Facebook. Pnas, 114 (12), 3035-3039. https://doi.org/10.1073/pnas.1617052114

Stine, Z.K., \& Agarwal, N. (2019). Characterizing the language-production dynamics of social media users. Soc. Netw. Anal. Min., 9, 60. https://doi.org/10.1007/ s13278-019-0605-7

Stine, Z.K., Khaund, T., \& Agarwal, N. (2018). Measuring the information-foraging behaviors of social bots through word usage. Proceedings of the IEEE/ACM international conference on advances in social networks analysis and mining (pp. 570-671). Barcelona, Spain. https://doi.org/10.1109/ASONAM.2018.8508811

Winata, C., \& Andangsari, E.W. (2017). Dispositional Gratitude and Social Comparison Orientation among Social Media Users. Humaniora, 8 (3), 229-237. https://doi. org/10.21512/humaniora.v8i3.3620

\begin{abstract}
АННОТАЦИЯ
Вступление. Цель исследования - системное описание концепта социальные медua/social media в русском и английском языковом сознании. Статья состоuт из двух частей. Первая часть посвящена исследованию концептов по данным серии психолингвистических экспериментов. Во второй части рассматривается представленность концептов в корпусной лингвистике и формируются полевая и когнитивно-классификационная модели концептов. В первой части статьи рассматриваются номинативные поля концепта социальные медиа / social media и его субконцептов; производится когнитивная интерпретация и сравнительный анализ данных на русском и английском языках.

Методы исследования. Методом субъективной дефиниции устанавливается структура концептов социальные медиа/social media. Методом свободного ассоциативного эксперимента выявляется структура субконцептов
\end{abstract}


(социальная cemь, Facebook, Instagram и др.). Процедура когнитивной интерпретации устанавливает классификационные когнитивные признаки концепта. Значимость количественного анализа диагностировалось методом углового преобразования Фишера (критерий $\varphi$ ).

Результаты. Концепт социальные медиа / social media можно отнести к базовым социальным концептам: коммуникация, интерперсональные отношения. С другой стороны, концепт можно отнести к концептамрелятивам, которые отражают опыт социального взаимодействия пользователей и содержат значительное число оценочных предикатов в номинативном поле. Данная нечеткость определения отражает тезис о размытых и условных границах концепта, его "полиаппелируемости» и «многомерности». Универсальными чертами концепта социальные медиа/sоcial media в русском и английском дискурсах являются идентичная когнитивноклассификационная структура, различия проявляются только на периферии. Концепт социальные медиа/social media обладает свойством социо- и культурспецифичности, на что указывает характер и распределение реакций в зоне ядра и периферии в различных экспериментах.

Выводы. Результаты исследования могут быть полезны в развитии психолингвистики 2.0, компьютерной лингвистики (OCR, ASR, Data Mining, машинный перевод и пр.), лексикографии, Big Data и пр.

Ключевые слова: социальные медиа, социальные сети, психолингвистика 2.0, языковое сознание, психолингвистический эксперимент, английский язык, русский язык.

\section{Шляхова Світлана \& Клюєв Микита. Соціальні медіа в англійській і російській мовній свідомості. Стаття 1. Психолінгвістичні експерименти}

\section{АНОТАЦІЯ}

Вступ. Мета дослідження - системний опис концепту соціальні медіa/social media в російській і англійській мовній свідомості. Стаття складається з двох частин. Перша частина присвячена дослідженню концептів за даними серії психолінгвістичних експериментів. у другій частині розглядається представленість концептів в корпусній лінгвістиці і формуються польова й когнітивно-класифікаційна моделі концептів. У першій частині статті розглядаються номінативні поля концепту соціальні медіa/social media i його субконцептів; проводиться когнітивна інтерпретація й порівняльний аналіз даних російською та англійською мовами.

Методи дослідження. Методом суб'єктивної дефініції встановлюється структура концептів соціальні медіa/social media. Mетодом вільного асоціативного експерименту виявляється структура субконцептів (соціальна мережа, Facebook, Instagram та ін.). Процедура когнітивної інтерпретації встановлює класифікаційні когнітивні ознаки концепту. Значимість кількісного аналізу діагностувалося методом кутового перетворення Фішера (критерій $\varphi$ ). 
Результати. Концепт соціальні медіa/social media можна віднести до базових соціальних концептів: комунікація, інтерперсональні відносини. 3 іншого боку, концепт можна віднести до концептів-релятивів, які відображають досвід сочіальної взаємодії користувачів і містять значну кількість очіночних предикатів у номінативному полі. Дана нечіткість визначення відображає теза про розмиті й умовні межі концепту, його «поліапеляційності» $i$ "багатовимірності». Універсальними рисами концепту сочіальні медіa/social media в російських та англійських дискурсах є ідентична когнітивно-класифікаційна структура, відмінності виявляються лише на периферії. Концепт соціальні медіа/social media має властивість соціо-та культуроспецифічності, на що вказує характер і розподіл реакцій у зоні ядра й перифрерії в різних експериментах.

Висновки. Результати дослідження можуть бути корисні для розвитку психолінгвістики 2.0, комп'ютерної лінгвістики (OCR, ASR, Data Mining, машинний переклад тощо), Лексикографії, Big Data та ін.

Ключові слова: сочіальні медіа, соціальні мережі, психолінгвістика 2.0, мовна свідомість, психолінгвістичний експеримент, англійська мова, російська мова. 